\title{
ТЕОРЕТИЧНІ АСПЕКТИ ВИКОРИСТАННЯ РИЗИК-ОРІЕНТОВАНОГО ПІДХОДУ ПРИ ЗДІЙСНЕННІ ДІЯЛЬНОСТІ САНІТАРНО-ЕПІДЕМІОЛОГІЧНИХ ЗАКЛАДІВ ЗБРОЙНИХ СИЛ УКРАЇНИ ЗА ДОТРИМАННЯМ ВИМОГ САНІТАРНОГО ЗАКОНОДАВСТВА
}

\author{
С.О. Моргун1, А.А. Заудальська², О.М. Іванько², І.В. Огороднійчук², \\ О.А. Бєлов², В.І.Нихоца1 ${ }^{1}$ О. Г. Смірнов² \\ ${ }^{1}$ Командування Медичних сил Збройних Сил України, м. Київ Україна \\ 2 Украӥнська військово-медична академія, м. Київ Україна
}

\begin{abstract}
Мета дослідження: аналіз та узагальнення даних літератури щодо визначення терміну «ризик» та «ризик-орієнтований підхід» та його застосування у практичному аспекті діяльності санітарноепідеміологічних закладів Збройних Сил України за дотриманням вимог санітарного законодавства.

Матеріали та методи: Застосовували методи дослідження (діалектичний, історичний, емпіричний, спостереження, порівняння, діалектичний, систематизації, моделювання, узагальнення). Здійснено вивчення нормативно - правової бази та зарубіжної літератури, які представляють весь спектр питань з предмету дослідження.

Результати. В статті авторами проаналізовано теоретичні основи поняття «ризик»та «ризикорієнтований підхід». Доведено, що перехід на роботу за ризик-орієнтовним підходом буде сприяти: підвищенню результативності, уніфікації та стандартизації контрольно-наглядової діяльності; здійсненню диференційованого підходу до проведення перевірок за дотриманням вимог законодавства $з$ урахуванням потенційного ризику заподіяння шкоди здоров'ю військовослужбовців.

Висновки. Проаналізовано дефініцію поняття «ризик», «ризик-орієнтований підхід» та їх сучасні інтерпретації. Показана важливість використання ризик-орієнтованого підходу організації діяльності за дотриманням вимог санітарного законодавства для забезпечення санітарно-епідеміологічного благополуччя особового складу. Це дозволяє: виявляти пріоритетні фактори ризику, оптимізувати діяльність епідеміологічних закладів Збройних Сил України, оцінювати ризики і на їх основі приймати управлінські рішення.
\end{abstract}

Ключові слова: ризик, ризик здоров'ю, ризик-орієнтована модель, санітарно-епідеміологічне благополуччя особового складу.

Вступ. Відсутність єдиного підходу до понять «ризику» і «ризику здоров'ю» призводить до серйозних правових труднощів при використанні результатів оцінки ризику, при застосуванні його у діяльності, прийнятті управлінських рішень на їх основі. Методологія аналізу ризику здоров'ю $\epsilon$ сьогодні загальноприйнятою основою діяльності по забезпеченню санітарноепідеміологічного благополуччя населення, захисту здоров'я громадян від негативного впливу різнорідних факторів, створення безпечного середовища проживання.

Метою дослідження $\epsilon$ аналіз та узагальнення даних літератури щодо визначення термінів «ризик» та «ризикорієнтований підхід» та їх застосування у практичному аспекті контрольно-наглядової діяльності санітарно-епідеміологічних закладів Збройних Сил України за дотриманням вимог санітарного законодавства.

Матеріали та методи досліджень. Застосовували методи дослідження (діалектичний, історичний, емпіричний, спостереження, порівняння, діалектичний, систематизації, моделювання, узагальнення).. Здійснено вивчення нормативно - правової бази та зарубіжної літератури, які представляють весь спектр питань з предмету дослідження. Вивчення зарубіжної та вітчизняної літератури здійснювалось $\mathrm{y}$ напряму узагальнення, систематизації та групування поглядів науковців щодо сутності, концепції ризик-орієнтованого підходу.

Результати дослідження та їх обговорення. Сьогодні існує безліч тлумачень поняття «ризик», що вказує на невизначеність у розумінні його сутності та породжує труднощі під час прийняття управлінських рішень. Це ускладнює можливість запобігання або зменшення можливих негативних наслідків та втрат у діяльності господарюючих суб'єктів. Спроби різних авторів розглядати ці терміни як синоніми або надання їм певного змісту, були взаємно неузгоджені [1].

Існують дві основні версії походження терміну «ризик». За однією 3 них, слово «ризик» іспано-португальського походження і означає «підводна скеля» (недарма «ризик» 
схожий на «риф»), тобто небезпека. Згідно 3 іншою версією, термін «ризик» походить від латинського «risicare», що означає «зважитися» [2].

y англомовну літературу слово «risk» прийшло пізніше, в середині XVIII ст, з Франції як слово «risque» (ризикований, сумнівний). Розвиток підприємництва стало ключовим стимулом розвитку теоретичних положень поняття «ризику» та його аналізу. В якості функціональної

характеристики підприємництва це поняття вперше було розглянуто в XVII ст. французьким економістом Р. Кантільйоном [3].

Одним із перших, хто в науковому форматі почав вивчати ризик був американський вчений Френк Найт, його основні ідеї лягли в основу праці «Ризик, невизначеність і прибуток» (1921р.). Ризик, за
Ф. Найтом, являє собою об'єктивну ймовірність тієї чи іншої події і може бути виражений кількісно, зокрема, у вигляді математичного ймовірного розподілу доходів. Вищенаведені положення стосуються економічного ризику, визначеного як «стан невпевненості в результатах угоди, інвестиційної діяльності, купівлі або продажу» [4]. У сучасній науковій літературі розглядається кілька різновидів ризику 3 притаманними їм певними особливостями.

Досить достовірне визначення поняття «ризик» міститься в керівництві ISO 73:2009 «Менеджмент ризику. Терміни та визначення» [5]. У цьому документі ризик розглядається як невизначеність щодо досягнення цілей.

Таким чином, можливо узагальнити різні визначення ризику за формулюванням різних авторів (табл.1) [7-10]:

Таблищя 1

\section{Визначення ризику за даними різних джерел}

\begin{tabular}{|c|c|c|}
\hline $\begin{array}{l}\text { № } \\
\text { 3a/п }\end{array}$ & Джерело або автор & Визначення ризику: ризик - це \\
\hline 1 & $\begin{array}{l}\text { Risk Management } \\
\text { Standard FERMA }\end{array}$ & комбінація ймовірності настання події і її наслідків \\
\hline 2 & $\begin{array}{l}\text { ISO } 31000 \quad \text { Risk } \\
\text { management. Principles } \\
\text { and guidelines }\end{array}$ & $\begin{array}{l}\text { вплив невизначеності на цілі; вплив - відхилення від того, що } \\
\text { очікується }\end{array}$ \\
\hline 3 & $\begin{array}{lr}\begin{array}{lr}\text { Enterprise } \\
\text { Management }\end{array} & \text { Risk } \\
\text { Integrated FRM)- } \\
\text { Standard COSO }\end{array}$ & $\begin{array}{l}\text { події, вплив яких } € \text { негативним, які заважають створенню або ведуть } \\
\text { до зниження вартості }\end{array}$ \\
\hline 4 & С. Ожегов & $\begin{array}{l}\text { можливість небезпеки чи дія «на удачу» в надії на щасливий } \\
\text { результат [6] }\end{array}$ \\
\hline 5 & Дж. Морган & ступінь невизначеності одержання майбутніх чистих доходів [7] \\
\hline 6 & О. Новікова & $\begin{array}{l}\text { перший крок розвитку небезпеки, за яким послідовно виникає } \\
\text { загроза, котра переростає у виникнення небезпечної події, що } \\
\text { негативно впливає на безпеку людського та соціального розвитку [8] }\end{array}$ \\
\hline 7 & $\begin{array}{l}\text { Е. Лібанова, В. Горбулін, } \\
\text { С. Пирожков та ін. }\end{array}$ & $\begin{array}{l}\text { потенційна характеристика дії, що виявляється у можливості } \\
\text { негативних ї̈ наслідків. Видокремлюють такі групи ризиків: } \\
\text { матеріальні - моральні; значні - незначні; передбачувані } \\
\text { непередбачувані; поточні - довгострокові; актуальні } \\
\text { відтерміновані [9] }\end{array}$ \\
\hline 8 & Ф. Найт & $\begin{array}{l}\text { «Ризик є невизначеністю, котру можна виміряти; як міра } \\
\text { невизначеності він дорівнює добутку ймовірності настаняя } \\
\text { несприятливої події та величини завданих збитків, тобто } \\
\text { характеризується наявністю джерела небезпеки й вразливості } \\
\text { об'єкта» [10] }\end{array}$ \\
\hline
\end{tabular}

Здебільшого поняття ризику відображає міру частоти настання події, в основі якої лежить їі ймовірна характеристика. 3 наведеними визначеннями терміну «ризик» існують визначення ризику з диференціацією по певних наслідках (екологічний, економічний, демографічний і ін.). У цьому ряду на одне з перших місць виходить ризик для здоров'я [11].
Міжнародно-правові акти, такі як Рекомендації В0О3 (1978), визначають ризик як «очікувану частоту небажаних ефектів, що виникають від заданого впливу забруднювача». Згідно Глосарію Американського агентства охорони навколишнього середовища (US EPA) (2011), ризик $\epsilon$ «ймовірність пошкодження, захворювання або смерті при певних 
обставинах. Кількісно ризик виражається величинами від нуля (що відображає впевненість в тому, що шкода не буде завдана) до одиниці (що відбиває впевненість в тому, що шкоди буде завдано)».

Стосовно до впливу несприятливих факторів навколишнього середовища ризик це очікувана частота шкідливих (небажаних) ефектів у населення, що виникають від заданого впливу забруднюючої речовини (WHO, 2000).

Резюмуючи, можна стверджувати, що хоча ризики - складне і багатопланове поняття, але йому притаманні власні особливості, що дає можливість також дати наступну дефініцію: ризики - це явища чи події, ймовірне чи передбачуване настання яких призведе чи може призвести до негативних наслідків. Таке визначення $\epsilon$ найбільш загальним i значною мірою відповідає поняттю ризик-менеджменту, що буде сприяти ефективнішому управлінню ризиками.

Таким чином, слід зазначити, що єдине визначення терміну «ризик» до теперішнього часу не прийнято. Разом з тим необхідно відзначити присутність в переважній більшості ключових понять - «ймовірність події», нанесення «шкоди (збитку)» внаслідок цієї події.

Технології та методи управління ризиком для здоров'я населення в зв'язку з несприятливою дією соціально-економічних, санітарно-гігієнічних і поведінкових факторів, що реалізуються на основі теорії ризику, є однією 3 найбільш результативних i ефективних методологій в сфері забезпечення санітарно-епідеміологічного благополуччя населення на всіх рівнях суб'єктів управління [12].

Орієнтація державних систем нагляду на методологію оцінки ризиків була обумовлена необхідністю вирішення двох основних завдань: підвищення ефективності контрольно-наглядової діяльності та підвищення комфортності ведення бізнесу. За результатами проведеного Хемптоном дослідження було встановлено, що основний тягар державного контролю (нагляду) несе малий бізнес, витрачає чимало часу і зусиль на підготовку звітної документації. Ключова рекомендація доповіді Хемптона полягала у впровадженні ризик-орієнтованого підходу в практику всіх державних органів: основний контроль повинен вестися щодо організацій, що мають найвищий ступінь ризику, тоді як суб'єкти, які протягом ряду років не порушували встановлені вимоги, повинні піддаватися мінімальним заходам перевірок. Принципи та рекомендації доповіді лягли в основу Кодексу практики регуляторних органів країни [13], який $\epsilon$ нормативним документом Департаменту у справах бізнесу, підприємництва та регуляторної реформи і встановлює обов'язкові для виконання норми і принципи реалізації державного контролю. Ці ж матеріали були використані при розробці Базового закону про державний контроль i санкції. Згідно з цим документом контрольнонаглядові органи повинні забезпечити ефективне використання наявних у них ресурсів через застосування оцінки ризиків на основі значущих і якісних даних про діяльність об'єкта аудиту.

Контролюючі органи повинні враховувати попередні випадки порушень вимог безпеки і ступінь ризику, наявність системи з управління ризиками в організації, компетенцію керівництва і його готовність до виконання встановлених вимог. При цьому декларується, що органи державного контролю повинні залучати господарюючі суб'єкти (суб'єкти нагляду) до розробки методики по оцінці ризику і інформувати про ці методи всі зацікавлені сторони. Першочергова увага має бути сфокусована на об'єктах, які мають дві ознаки: порушення вимог може призвести до небезпечних наслідків; на об'єкті нагляду існує ризик недотримання вимог. При цьому кожна контролююча організація має право визначати додаткові параметри, від яких залежить періодичність проведення контрольно-наглядових заходів (в рамках загальних підходів). Прикладом такої системи контролю $є$ НАССР, який розроблений для здійснення контролю безпеки при виробництві продуктів харчування, вирощування i переробки сільськогосподарської продукції, БАДів, кормів для тварин, іншої харчової продукції, а також в сфері громадського харчування [14].

3 метою зниження адміністративного навантаження на суб'єкти господарської діяльності при одночасному підвищенні ефективності функціонування органів можна використати ризик-орієнтовану модель контрольно-наглядової діяльності, засновану на таких принципах:

- використання методів оцінки ризиків здоров'ю особового складу на всіх етапах організації контрольно-наглядової діяльності; 
- класифікація піднаглядних об'єктів залежно від ступеня загрози і ризику заподіяння шкоди життю і здоров'ю громадян;

- диференційний підхід до проведення контрольно-наглядових заходів 3 концентрацією зусиль на об'єктах, що формують неприпустимий ризик для здоров'я;

- системність інформаційноаналітичного забезпечення завдань з оцінки та управління ризиками здоров'ю;

- врахування показників економічної ефективності контрольно-наглядових заходів та заходів з управління ризиками здоров'ю;

- оптимізація контрольно-наглядової діяльності за системою критеріїв ризику, шкоди здоров'ю особового складу та економічних втрат.

Слід відмітити, що ризик-орієнтований підхід для наглядових органів $\epsilon$ механізмом розподілу своїх ресурсів під час виконання функцій, тобто оптимізація наглядової діяльності, що досягається шляхом: диференціації частоти та ступеня перевірок; перенаправлення контрольних функцій на інформаційно-консультативну діяльність; відсутність переліку об'єктів, які підлягають обов'язковій перевірці, а також переліку об'єктів, які не підлягають перевіркам.

Належний розподіл на ступені ризику забезпечить раціональне використання ресурсів органів державного нагляду (контролю) шляхом встановлення періодичності проведення планових заходів зі здійснення державного нагляду (контролю).

Потенційний ризик заподіяння шкоди життю та здоров'ю громадян необхідно розглядати як наслідок порушення господарюючим суб'єктом обов'язкових вимог санітарного законодавства при здійсненні своєї діяльності, повне дотримання яких в більшості випадків виключить появу ризиків для здоров'я i життя людини. Ризик заподіяння шкоди здоров'ю виступає в якості міри безпеки. Імовірність негативного впливу ризиків заподіяння шкоди здоров'ю на якість життя викликає необхідність управління ними та повинне бути спрямоване на їх мінімізацію і прийняття ефективних заходів щодо запобігання ситуацій, які спричинили за собою порушення санітарного законодавства $[15,16]$.

На сьогодні Положенням про Державну службу України з питань безпечності харчових продуктів та захисту споживачів, затвердженим постановою Кабінету Міністрів України від 02 вересня 2015 року № 667, передбачено, що Держпродспоживслужба $\epsilon$ центральним органом виконавчої влади, який реалізує державну політику, у тому числі у сфері санітарного законодавства. ступінь ризику від провадження господарської діяльності у сфері санітарного та епідемічного благополуччя населення оцінюється за критеріями згідно Постанови КМ України від 27.12.2018 p. № 1164 [17].

Натомість, в 3С Україні, попри наявність значної кількості нормативно-правових актів, які регулюють відносини у сфері складових компонентів системи (охорони здоров'я, забезпечення санітарного та епідемічного благополуччя особового складу, охорони навколишнього природного середовища та в інших сферах), відсутній нормативно визначений порядок здійснення санітарноепідеміологічного нагляду за дотриманням вимог санітарного законодавства органами військового управління, військовими частинами, ВВНЗ та ВНП ВЗО України, установами і організаціями 3С України, а також підприємствами, що належать до сфери управління Міністерства оборони України, який би враховував ризик заподіяння шкоди здоров'ю і життю особового складу.

Так, Законом України від 24.03.1999 року «Про Статут внутрішньої служби Збройних Сил України» передбачено проведення санітарно-гігієнічних та протиепідемічних заходів. Наказом начальника Генерального штабу Збройних Сил України від 26.12.2013 року №317 введено в дію «Керівництво 3 медичного забезпечення Збройних Сил України», якими передбачені відповідні заклади (санітарно-епідеміологічні управління), на які покладається проведення заходів санітарного нагляду у Збройних Силах України.

Також згідно п.4 підпункту 95 Постанови Кабінету Міністрів України від 26.11.2014 року № 671 «Про затвердження Положення про Міністерство оборони України» Міноборони, відповідно до покладених на нього завдань, «...організовує забезпечення санітарного та епідемічного благополуччя військовослужбовців у Збройних Силах та здійснює державний санітарноепідеміологічний нагляд на підпорядкованих їм територіях, об'єктах, у військових частинах і підрозділах» $[18,19]$. Наказом МО України від 03.04.2020 № 108 «Питання Міністерства оборони України», регламентовано розподіл основних завдань і функцій, визначених Положенням про МО України. Основним виконавцем напряму «Організація 
забезпечення санітарного та епідемічного благополуччя військовослужбовців у Збройних Силах та здійснення державного санітарно-епідеміологічний нагляду на підпорядкованих їм територіях, об'єктах, у військових частинах і підрозділах» (п.95) визначені Збройні сили України.

Але, невирішеним $\epsilon$ визначення критеріїв, за якими оцінюється ступінь ризику і періодичність проведення планових заходів 3 перевірки військових частин (установ, закладів) за дотриманням вимог санітарного законодавства. 3 метою впровадження ризикорієнтованої моделі контрольно-наглядової діяльності за дотриманням вимог санітарного законодавства необхідно класифікувати об'єкти нагляду і види їх діяльності за потенційним ризиком заподіяння шкоди здоров'ю особовому складу ЗС України. В той же час, належний розподіл на ступені ризику забезпечить раціональне використання

\section{Висновки}

1. Показано, що ризик як ймовірність небажаних подій $є$ невід'ємним компонентом життя людини.

2. Використання ризик-орієнтованого підходу організації контрольно-наглядової діяльності за дотриманням вимог санітарного законодавства для забезпечення санітарноепідеміологічного благополуччя особового складу дозволяє: виявляти пріоритетні

\section{Література}

1. Андрейчикова А. М. Еволюція поглядів на проблему ризику в економічній науці. Економічний вісник. 2014. №1. С. 38-49.

2. Банковский менеджмент учебник. Под ред. дра екон. наук, проф. О. И. Лаврушина. - 2-е изд. перераб. и доп. М.: КНОРУС, 2009. 560 с.

3. Устенко О.Л. Теория экономического риска: Моногр. К.: МАУП, 1997. 164 с.

4. Frank H. Knight. The Meaning of Risk and Uncertainty. In: F.Knight. Risk, Uncertainty, and Profit. Boston: Houghton Mifflin Co, 1921, p. 210-235.

5. Національний стандарт України. Керування ризиками. Визначення термінів. ДСТУ ISO Guide 73:2009.

6. Ожегов С.И. Толковый словарь русского языка. Под ред. проф. Л.И. Скворцова. Изд. 28-е, перераб. Москва: 000 «Издательство «Мир и Образование», 2012. $1376 \mathrm{c}$.

7. Forbes John Douglas. J.P. Morgan, Jr., 1867-1943. Charlottesville: University Press of Virginia, 1981. 262 p.

8. Новікова О. Ф. Оцінка соціальних ризиків в регіонах України як підстава для прийняття управлінських рішень щодо їх подолання. Режим доступу: http://old.niss.gov.ua. ресурсів органів державного нагляду (контролю) шляхом встановлення періодичності проведення планових заходів зі здійснення державного нагляду (контролю).

Перехід на роботу за вказаним принципом буде сприяти:

попередженню виникненню загрози життю і здоров'ю особового складу із моделюванням різних видів потенційних ризиків здоров'ю;

підвищення результативності, уніфікації та стандартизації контрольно-наглядової діяльності;

впровадження сучасних інформаційних технологій для ефективного визначення рівнів ризику заподіяння шкоди здоров'ю і життю особового складу;

здійсненню диференційованого підходу до проведення перевірок за дотримання вимог законодавства 3 урахуванням потенційного ризику заподіяння шкоди.

фактори ризику, оптимізувати контрольнонаглядову діяльність, оцінювати і надавати пропозиції керівникам, які приймають рішення.

3. Виникла нагальна потреба у визначення критеріїв, за якими оцінюється ступінь ризику і періодичність проведення планових заходів 3 перевірки військових частин за дотриманням вимог санітарного законодавства.

9. Лібанова Е.М., Горбулін В.П., Пирожков C.I. Політика інтеграції українського суспільства в контексті викликів та загроз подій на Донбасі: нац. доп. За ред. Е.М. Лібанової. Київ : НАН України, 2015. 363 c.

10. Найт Ф. Риск, неопределенность и прибыль. Москва: Дело, 2003. 359 с.

11. Кузьмина Е.А., Винокурова М.В., Газимова В.Г. и др. Практика и перспективы применения экономических инструментов обоснования и оценки эффективности мер по управлению риском и обеспечению санитарно-эпидемиологического благополучия населения (на примере Свердловской области). Здоровье населения и среда обитания. 2010. № 1. С. 20-25.

12. Guidance Regulators' Compliance Code: for insolvency practitioners https://www.gov.uk/government/publications/regul ators-compliance-code-for-insolvency-practitioners.

13. Круглов Кирило. ХАССП: Практичний посібник з впровадження 2018 Ridero ст - 162.

14. Шаронова Д.С. Техническое регулирование процессов качества жизни: риски качества жизни. Сб. науч. тр.: прил. к журн. Вопр. соврем. науки и 
практики. Ун-т им. В.И. Вернадского. 2011. № 3 (34). C. 311-317.

15. Нижегородов Е.В. Анализ управления рисками качества жизни. Экономика и управление качеством: учет, анализ, методы, модели, инструменты и аудит: сб. науч. тр.: прил. к журн. Вопр. соврем. науки и практики. Ун-т им. В.И. Вернадского. Тамб. гос. техн. ун-т. Тамбов. 2008. Вып. 5. С. 248.

16. Про затвердження критеріїв, за якими оцінюється ступінь ризику від провадження господарської діяльності у сфері санітарного та епідемічного благополуччя населення та визначається періодичність здійснення планових заходів державного нагляду (контролю) Державною службою 3 питань безпечності харчових продуктів та захисту споживачів: постанова Кабінету Міністрів України від

\section{References}

1. Andreichikova A. M. (2014). Evolution of views on the problem of risk in economic science. Economic Bulletin, 1. 38-49. [In Ukrainian].

2. Lavrushin O.I. (2009). Banking Management Textbook. M.: KNORUS,. 560 p. [In Russian].

3. Ustenko A. L. (1997). Theory of economic risk: Monogr. IAPM, 164 s.. [In Russian].

4. Frank H. Knight. (1921). The Meaning of Risk and Uncertainty. In: F.Knight. Risk, Uncertainty, and Profit. Boston: Houghton Mifflin Co, p. 210-235.

5. National standard of Ukraine. Risk management. Definition of terms. DSTU IS Guide 73:2009. [In Ukrainian].

6. Ozhegov S.I. (2012). Explanatory dictionary of the Russian language. Moscow: LLC «Publishing House» Peace and Education «, 1376 p. [In Russian].

7. Forbes John Douglas. J.P. Morgan, Jr. (1981). 1867-1943. Charlottesville: University Press of Virginia,. 262 p.

8. Novikova O. F. (2019). Assessment of social events in the regions of Ukraine as a source for the adoption of administrative decisions and times. Access mode: http://old.niss.gov.ua. [In Ukrainian].

9. Libanova E.M., Gorbulin V.P., Pirozhkov S.I. and in. (2015). Policy of integration of the Ukrainian suspension in the context of victories and threats to the Donbas: nat. add. National Academy of Sciences of Ukraine.363 p. [In Ukrainian].

10. Night F. (2003). Risk, uncertainty and profit. Moscow: Delo. 359 p. [In Russian].

11. Kuzmina E.A., Vinokurova M.V., Gazimova V.G. at all (2010). The practice and prospects of using economic tools to justify and evaluate the effectiveness of measures to manage risk and ensure the sanitary and epidemiological well-being of the population (using the example of the Sverdlovsk region). Population health and habitat. № 1. p. 20-25. [In Russian].

12. Guidance Regulators' Compliance Code: for insolvency practitioners
27.12.2018 p. № 1164 - Режим доступу: https://zakon.rada.gov.ua/laws/show/1164-2018\%D0\%BF\#Text.

17. Про Статут внутрішньої служби Збройних Сил України: закон України від 24.03.1999 № 548XIV - Режим доступу: https://zakon.rada.gov.ua/laws/show/548-14\#Text.

18. Про затвердження Положення про Міністерство оборони України: постанова Кабінету Міністрів України від 26.11.2014 № 671 - Режим доступу: https://zakon.rada.gov.ua/laws/show/6712014-\%D0\%BF\#Text.

19. Наказ МО України від 3.04.2020 року № 108 Питання Міністерства оборони України - Режим доступу:

https://www.mil.gov.ua/content/mou_orders/mou_2 020/108_mou.pdf.

https://www.gov.uk/government/publications/regul ators-compliance-code-for-insolvency-practitioners

13. Kruglov Kirill (2018). HACCP: Practical guide to the implementation. Ridero Article. 162. [In Ukrainian].

14. Sharonova D.S. (2011). Tehnicheskoe regulirovanie processov kachestva gizni:riskami kachestva gizni. Universitet. im. V.I. Vernadskogo. № 3(34). P. 311-317. [In Russian].

15. Nigegorodov E.V. (2008). Analiz upravleniya riskami kachestva gizni. Ekonomika $i$ upravlenie kachestvom: uchet, analiz, metodu, modeli, instrument $i$ audit: sb. nauch. tr.: pril. $k$ gurn. Vopr. sovrem. nauki $i$ praktiki. Un-t. im. V.I. Vernadskogo.Tamb. gos. tehn. unt. Tambov.. Vol. 5. P. 248. [In Russian].

16. On the approval of criteria for assessing the degree of risk from economic activities in the field of sanitary and epidemic well-being of the population and determining the frequency of planned measures of state supervision (control) by the State Service for Food Safety and Consumer Protection: Cabinet of Ministers Decision №1164 of 27.12.2018 - Access mode: https://zakon.rada.gov.ua/laws/show/1164-2018$\%$ D0\%BF\#Text.

17. About the Charter of internal service of the Armed Forces of Ukraine: the law of Ukraine of 24.03.1999 №. 548-XIV - the access Mode: https://zakon.rada.gov.ua/laws/show/548-14\#Text.

18. On approval of the Regulation on the Ministry of Defense of Ukraine: Resolution of the Cabinet of Ministers of Ukraine dated 26.11.2014 №. 671 - Access regime: https://zakon.rada.gov.ua/laws/show/6712014-\%D0\%BF\#Text.

19. Order of the Ministry of Defense of Ukraine on April 3, 2020, Rock No. 108 Food of the Ministry of Defense of Ukraine - Access mode. https://www.mil.gov.ua/content/mou_orders/mou_2 020/108_mou.pdf 


\title{
ТЕОРЕТИЧЕСКИЕ АСПЕКТЫ ИСПОЛЬЗОВАНИЯ РИСК-ОРИЕНТИРОВАННОГО ПОДХОДА ПРИ ОСУЩЕСТВЛЕНИИ ДЕЯТЕЛЬНОСТИ САНИТАРНО-ЭПИДЕМИОЛОГИЧЕСКИХ УЧРЕЖДЕНИЙ ВООРУЖЕННЫХ СИЛ УКРАИНЫ ЗА СОБЛЮДЕНИЕМ ТРЕБОВАНИЙ САНИТАРНОГО ЗАКОНОДАТЕЛЬСТВА
}

\author{
С.А. Моргун1, А.А. Заудальская², О.М. Иванько², И.В. Огороднийчук², \\ А.А. Белов ${ }^{2}$ В.И. Нихоца, А.Г Смирнов²
}

\author{
${ }_{1}^{1}$ Командование Медицинских сил Вооруженных Сил Украины, г. Киев Украина \\ гукраинская военно-медицинская академия, г. Киев Украина
}

Цель работы: анализ и обобщение данных литературы по определению термина «риск» и «рискориентированный подход» и его применение в практическом аспекте деятельности санитарноэпидемиологических учреждений Вооруженных Сил Украины за соблюдением требований санитарного законодательства.

Материалы и методы: применяли методы исследования (диалектический, исторический, эмпирический, наблюдения, сравнения, диалектический, систематизации, моделирование, обобщение). Осуществлено изучение нормативно - правовой базы, практического опыта и зарубежной литературы, представляющих весь спектр вопросов по предмету исследования.

Результаты. В статье авторами проанализированы теоретические основы понятия «риск» и «рискориентированный подход». Доведено, что переход на работу по «риск-ориентированного подхода» будет способствовать: повышению результативности, унификации и стандартизации контрольно-надзорной деятельности; осуществлению дифференцированного подхода $\kappa$ проведению проверок соблюдения требований законодательства с учетом потенциального риска причинения вреда здоровью военнослужащих.

Выводы. Проанализированы дефиниции понятий «риск», «риск-ориентированный подход» и их современные интерпретации. Показана важность использования риск-ориентированного подхода организации деятельности за соблюдением требований санитарного законодательства для обеспечения санитарно-эпидемиологического благополучия личного состава. Это позволяет выявлять приоритетные факторы риска, оптимизировать деятельность эпидемиологических учреждений Вооруженных Сил Украины, оценивать риски и на их основе принимать управленческие решения.

Ключевые слова: риск здоровью, управление риском здоровью, риск-ориентированная модель, санитарно-эпидемиологическое благополучие личного состава.

\section{THEORETICAL ASPECTS OF DEFINING THE RISK-BASED APPROACH IN THE OPERATION OF SANITARY AND EPIDEMIOLOGICAL INSTITUTIONS OF THE ARMED FORCES OF UKRAINE IN COMPLIANCE WITH SANITARY LEGISLATION}

\author{
S.A. Morgun ${ }^{1}$, A.A. Zaudalskaya ${ }^{2}$, O.M. Ivanko² ${ }^{2}$ I.V. Ogorodniychuk², \\ A.A. Belov' ${ }^{2}$, V.I. Nikhotsa', A.G. Smirnov ${ }^{2}$ \\ ${ }^{1}$ Medical Forces Command of the Armed Forces of Ukraine, Kiev, Ukraine \\ ${ }^{2}$ Ukrainian Military Medical Academy, Kiev, Ukraine
}

The purpose: analysis and generalization of literature data on the definition of the term «risk» and «riskoriented approach» and its application in the practical aspect of the activities of sanitary and epidemiological institutions of the Armed Forces of Ukraine for compliance with the requirements of sanitary legislation.

Materials and methods: We used research methods (dialectical, historical, empirical, observation, comparison, dialectical, systematization, modeling, generalization). The study of the regulatory and legal framework, practical experience and foreign literature, representing the entire range of issues on the subject of research, has been carried out.

Results. In the article, the authors analyzed the theoretical foundations of the concept of «risk» and «riskoriented approach». It was reported that the transition to work on a «risk-based approach» will contribute to: increasing the effectiveness, unification and standardization of control and supervisory activities; implementation of a differentiated approach to conducting inspections of compliance with legal requirements, taking into account the potential risk of harm to the health of servicemen.

Conclusions. The definitions of the concepts «risk», «risk-oriented approach» and their modern interpretations are analyzed. The importance of using a risk-oriented approach to organizing activities for compliance with the requirements of sanitary legislation is shown to ensure sanitary and epidemiological well-being of personnel. This makes it possible to identify priority risk factors, optimize the activities of epidemiological institutions of the Armed Forces of Ukraine, assess risks and, on their basis, make management decisions.

Keywords: health risk, health risk management, risk-based model, sanitary and epidemiological well-being of servicemen. 
Конфлікт інтересів відсутній.

Conflicts of interest: authors have no conflict of interest to declare.

\section{Відомості про авторів:}

Моргун C.O. В,С,F - начальник Санітарно-епідеміологічного управління Командування Медичних сил Збройних Сил України, e-mail: morhunsergey@gmail.com, ORCID iD: https://orcid.org/0000-0003-1890-7068

Заудальська A.A.,, ,D - молодший лейтенант медичної служби, слухач 2 курсу факультету підготовки військових лікарів Української військово-медичної академії.

Іванько О.М. A,B,C,D,E,F - д. мед. Н., доцент, начальник Науково-дослідного інституту проблем військової медицини Української військово-медичної академії, e-mail: ol ivanko@ukr.net, ORCID iD: https://orcid.org/0000-0002-5929-255X

Огороднійчук I.B. B,C,D,E,F - професор кафедри військово-профілактичної медицини Української військово-медичної академії, e-mail: iro4ka.ogo@ukr.net, ORCID iD: https://orcid.org/0000-0003-1063-1829

Белов О.А. В,C,F - науковий співробітник Науково-дослідного інституту проблем військової медицини Української військово-медичної академії, e-mail: aleksandr.belov5819@gmail.com, ORCID iD: https://orcid.org/0000-0001-7336-4874

Нихоца B.I. В,C,F - начальник санітарно-гігієнічного відділу Санітарно-епідеміологічного управління Командування Медичних сил Збройних Сил України, e-mail: nwi07@i.ua, ORCID iD: https://orcid.org/0000$\underline{0002-2236-1267}$

Смірнов О.Г В,C,D,E,F. - викладач кафедри військово-профілактичної медицини Української військовомедичної академії., e-mail: smirnov-kiev@ukr.net, ORCID iD: https://orcid.org/0000-0002-2251-1317

$A$ - концепція та дизайн дослідження; $B$ - збір даних; $C$-аналіз та інтерпретація даних;

D- написання статmi; E- редагування статmi; F- остаточне затвердження статті.

\section{Сведения об авторах:}

Моргун С.A. B,C,F - начальник Санитарно-эпидемиологичного управления Командувания Медицинских сил Вооруженных Сил Украины, e-mail: morhunsergey@gmail.com, ORCID iD: https://orcid.org/0000-0003-1890-7068

Заудальская A.A. B,C,D - младший лейтенант медицинской службы, слухач 2 курсу факультета подготовки военных врачей Украинской военно-медицинской академии. г. Киев

Иванько 0.M. A,B,C,D,E,F - д. мед. н., доцент, начальник Научно-исследовательского института проблем военной медицины Украинськой военно-медицинской академии, e-mail: ol ivanko@ukr.net, ORCID iD: https://orcid.org/0000-0002-5929-255X

Огороднийчук И.В. А,B,C,D,E,F - д. мед. н., доцент, професор кафедри военно-профилактической медицины Украинской военно-медицинской академии, e-mail: iro4ka.ogo@ukr.net, ORCID iD: https://orcid.org/0000-0003-1063-1829

Белов О.А. В,С,F- научный сотрудник Научно-исследовательского института проблем военной медицины Украинськой военно-медицинской академии, e-mail: aleksandr.belov5819@gmail.com, ORCID iD: https://orcid.org/0000-0001-7336-4874

Нихоца B.I. B,C,F - начальник санитарно-гигиенического отдела Санитарно-эпидемиологического управления Командования Медицинских сил Вооруженных Сил Украины, e-mail: nwi07@i.ua, ORCID iD: https://orcid.org/0000-0002-2236-1267

Смирнов А.Г.В,C,D,E,F - преподаватель кафедры военно-профилактической медицины Украинской военно-медицинской академии. e-mail: smirnov-kiev@ukr.net, ORCID iD: https://orcid.org/0000-0002-22511317

\section{Information about authors:}

Morgun S. B,C,D,E,F - Head of the sanitary and epidemiological department of the Command of the Medical Forces of the Armed Forces of Ukraine, Kyiv. e-mail: morhunsergey@gmail.com, ORCID iD: https://orcid.org/0000-0003-1890-7068

Zaudalska A.A. ${ }^{\text {B,C,D }}$ - JLt MS, student of the 2nd year of the faculty of training of military doctors of the Ukrainian Military Medical Academy. Kyiv

Ivanko 0.M. A,B,C,D,E,F - MD, PhD, Professor, the Head of Research Institute of Military Medicine of Ukraine Military Medical Academy, e-mail: ol_ivanko@ukr.net ORCID iD: https://orcid.org/0000-0002-5929-255X

Ogorodniychuk I.V.- MD, PhD, Professor, Professor of the Department of Military Preventive Medicine of the Ukrainian Military Medical Academy, e-mail: iro4ka.ogo@ukr.net, ORCID iD: https://orcid.org/0000-0003$\underline{\text { 1063-1829 }}$

Belov A.A. ${ }^{\text {B,C,F }}$ - researcher of Research Institute of Military Medicine of Ukraine Military Medical Academy, e-mail: aleksandr.belov5819@gmail.com, ORCID iD: https://orcid.org/0000-0001-7336-4874 
Nikhotsa V.I. B,C,F Head of the Sanitary and Hygienic Department of the Sanitary and Epidemiological Directorate of the Command of the Medical Forces of the Armed Forces of Ukraine, e-mail: nwi07@i.ua, ORCID iD: https://orcid.org/0000-0002-2236-1267

Smirnov 0.G. B,C,D,E,F - teacher of the Department of Military Preventive Medicine of the Ukrainian Military Medical Academy. e-mail: smirnov-kiev@ukr.net, ORCID iD: https://orcid.org/0000-0002-2251-1317

$A$ - research concept and design; $B$ - collection and/or assembly of data; $C$ - data analysis and interpretation;

$D$ - writing the article; $E$ - critical revision of the article; $F$ - final approval of the article.

Адреса для листування: вул. Московська,45/1, буд.33, м. Київ 01015 